\title{
TOWARDS NEW TYPOLOGY OF THE OWNERS-MANAGERS OF THE SMALL AND MEDIUM ENTERPRISES
}

\author{
Maris MILLERS (1)*, Elina GAILE-SARKANE(D) \\ Faculty of Engineering Economics and Management, Riga Technical University, \\ Kalnciema Street 6, LV-1048 Riga, Latvia
}

Received 28 February 2021; accepted 1 April 2021

\begin{abstract}
Purpose - individuals or families own and at the same time manage a large proportion of private enterprises. Previous studies mostly refer to owner-manager of the enterprise as an individual with own personal traits, styles and preferences. Purpose of this article is to propose a new typology of the owners-managers of the small and medium enterprises representing all variety, determined by their different ownership status and managerial authorities in companies.

Research methodology - research started with a systematic rapid literature review using an overview method. Data for research were collected through 52 semi-structured interviews with SME owner-managers representing broad range of industries and companies of different age. Key findings were discussed and approbated in two focus group discussions.

Findings - as a result of this research, a preliminary typology was developed, consisting of ten types of the SME owners-managers, with a brief description of each type constructed.

Research limitations - conclusions from this research are relevant to those SMEs analysed in this particular research and shall not be generalized without additional research and validation.

Practical implications - the typology suggested in this article provides a structured way to explore the diversity of SME owners-managers and raise understanding of their behaviour when planning, controlling and managing their business.

Originality/Value - the proposed typology is a step towards filling the knowledge gap caused by the lack of a holistic and systematic approach in addressing the diversity of the SME owners-managers.
\end{abstract}

Keywords: small and medium enterprises, management, owners-managers, family business.

JEL Classification: D22, G39, L26, M10, M12.

Conference topic: Contemporary Organizations Development Management.

\section{Introduction}

Small and medium sized enterprises (SMEs) are very important to economy. In 2018, there were slightly more than 25 million SMEs in the EU-28, SMEs accounted for $99.8 \%$ of all enterprises in the EU-28 non-financial business sector (NFBS), generating 56.4\% of value added and $66.6 \%$ of employment in the NFBS (European Commission, 2019).

Global crisis creates a difficult macroeconomic environment for SMEs in EU and worldwide. In 2016 SME employment finally recovered from the 2008/2009 economic and financial crisis and even slightly exceeded the 2008 level. All Member States except Latvia recorded growth in SME employment in 2016 (European Commission, 2017). The coronavirus pandemic starting in 2020 has caused large-scale loss of life and severe human suffering globally. It is an unprecedented public health crisis in living memory, which has also generated a major economic crisis, with a halt in production in affected countries and a collapse in consumption and confidence. SMEs again are to be affected by the current coronavirus (Organisation for Economic Co-operation and Development, 2020).

Individuals or families own and at the same time manage a large proportion of private enterprises. Literature often refers to owner-manager of the enterprise as a sole and individual person. Many researches have been conducted to identify management traits and styles of these individuals. However, companies can have several founders and co-owners. Managers of such enterprises can be given various levels of authority in planning, communication and decision making. Behaviour of the owner-manager in such situations may differ significantly from that of the individual owner-manager. Holistic view and structured approach on this diversity is still missing.

\footnotetext{
*E-mail: maris.millers@rtu.lv
} 
As significance of the SMEs grow, also a number of researches on these enterprises increases. Range of research topics on SMEs have broaden and now it covers managerial issues, systemic approaches in enterprise management, as well as psychology and behaviour of owners, individuals and groups. There is an opinion present among entrepreneurs that founder or owner shall be substituted by professional manager to avoid stagnation of company or decline in business performance. Business literature also sometimes share this belief that founders have insufficient management capabilities. However, there are research data which do not support this opinion.

Three enterprise categories defined in Europe distinguish SMEs by its size - micro enterprises, small enterprises and medium sized enterprises. This category split was adopted in 2005, therefore literature and statistics about small business published before 2005 and also after shall be reviewed carefully. Some information and conclusions drawn about small business can be relevant to companies nowadays recognised as microbusiness or microenterprises.

Large number of enterprises in SME sector creates high variety in forms of running business and also variation in forms of enterprise ownership. Literature refers to founders, single owners, family business, partnerships, each representing some form of ownership or influence over SME. However, there is no formal classification developed yet covering all field of SMEs and their owners-managers.

Main goal of this article is to propose a new typology of the owners-managers of the small and medium enterprises. Such typology would provide structured way to better understand diversity of owners-managers of SMEs and raise understanding of their behaviour when planning, controlling and managing their business. Following tasks were set to achieve main goal:

1. Conduct systematic literature review to understand previous studies on the management of SMEs and owner-managed companies, types and diversity of SME owners and managers.

2. Collect data through semi-structured interviews conducted with owners-managers of different SMEs to understand their ownership status, historical relationship to organization, managerial role and style.

3. Develop typology consisting on finite number of types with relevant type descriptions.

4. Validate the typology and each type using a focus group discussion.

As result this research preliminary typology consisting of ten types of the SME's owners-managers was developed with brief descriptions for each constructed type.

This article elaborates further on authors previous research on owners-managers of small and medium sized enterprises (Millers et al., 2016) and their diversity (Millers, 2017).

\section{Background}

Research on small businesses, business owners and managers has a history of nearly 100 years. The American small-business policy in the 1930s was intended to protect small business, which was believed to be disappearing and much weaker than big business. Two types of small business with different behaviour were recognised by some policy makers - one type had a competitive character, while the other had an anti-competitive character (Ikuta, 2000).

During last 40 years, with increasing role of small and medium sized business in economy, research on SMEs has intensified and broaden. Research topics now cover managerial issues, systemic approaches in enterprise management, as well as psychology and behaviour of owners, individuals and groups.

There are three enterprise categories defined in Europe to distinguish SMEs by its size: micro enterprises, small enterprises and medium sized enterprises. Micro enterprise as those who have less than 10 employees. Small enterprises have from 10 to 49 employees, and medium sized enterprises are those who have from 50 to 249 employees (European Comission, 2005). The vast majority - almost 93\% of SMEs are micro enterprises with less than $10 \mathrm{em}-$ ployees. These three categories were adopted in 2005, and this must be taken into account when reviewing literature and statistics about small business. Research and data about small business, published before 2005, and also after this period, actually can carry information and conclusions about businesses and enterprises which nowadays is recognised as microbusiness or microenterprises.

Entrepreneur as an individual whose function is to carry out new combinations of means of production was described by Schumpeter (Schumpeter, 1934). Schumpeter also was one of first who identified the entrepreneur as an entity distinct from business owners and managers. According to Schumpeter, entrepreneur is an innovator and a driver for growth, however most of small or micro-business owners or self-employed persons are not entrepreneurial, in a Schumpeterian sense.

One of the first who opened ground for study of small business was David Birch in 1979 with his report "The Job Generation Process" (Birch, 1979). Report showed that, contrary to the prevailing conventional wisdom of that time, most new jobs in the US are created by small companies. Birch was also among the first to emphasize the importance of rapidly growing firms, and his study caught the attention of politicians as well as scientists in US and abroad. To describe rapidly growing firms, he introduced the nowadays widely-used term "gazelles".

Research focusing on owners-managers of SMEs started with analysing particular managerial and supervisory issues (Deeks, 1970), processes of financial control (Dhaliwal et al., 1982) and making investment decisions (James, 
1999). Gradually, systemic approach to business management in family firms (Goffee \& Scase, 1985) as well as owner-managed SMEs (Wang et al., 2007) became as point of interest.

Since 1990s aspects of culture, psychology and behaviour also are studied in context of SMEs and owner managed enterprises. Edgar Schein analysed what role founder plays in creating organizational culture (Schein, 1995). According to Schein, organisational culture is a result of development of ideas that have formed certain pattern of assumptions. Business founders bring these ideas to adopt or expand then to selected group of closest employees. Schein noticed that there is a problem for firms with a strong founder generated culture to transfer this organisation culture as a whole to next generations.

Few studies have examined the role of owner-manager as a facilitator of learning in their businesses. Some research has emphasised that small business owner-managers are rarely directly involved in facilitating employees' learning (Coetzer et al., 2019).

Carland et al. (1984) suggested two conceptualizations how to differentiate entrepreneurs from small business owners and managers, and how to distinguish entrepreneurial ventures from small business (Carland et al., 1984). They defined that a small business owner is an individual who establishes and manages a business for the principal purpose of furthering personal goals. For a small business owner, the business is the primary source of income and it will consume the majority of one's time and resources. The business is perceived as an extension of owner's own personality and is tightly bound with family needs and desires.

More research resulted in similar conclusions. Birley et al. (1999) states that small sized companies often operate as an extension of the ethos of their owner-managers (Birley et al., 1999). Intentions of owner to operate a business is not only in generating wealth and job opportunities for the family but also in cherishing autonomy and sustaining an enviable lifestyle.

Study conducted in Latvia in 2012 (Ščeulovs \& Gaile-Sarkane, 2012) came to conclusion that a large part of micro-enterprise owners use the existing legal framework on micro-enterprises primarily to legalise income and minimise taxes, and such companies therefore shall not be considered as entrepreneurs.

Distinction between small business activity and entrepreneurship in terms of Schumpeter was emphasised in research of Henrekson and Sanandaji (2014). They argued that number of small enterprises is not appropriate to measure level of entrepreneurship in country. As an illustration for this argument, if measured by number of SMEs, entrepreneurship level in Egypt shall be higher than in USA, which is a misleading conclusion. Their study included analysis of firms founded by the billionaires and establishing whether or not each of these individuals is a self-made entrepreneur. Results showed that most of entrepreneurs in their research $(58 \%$ worldwide and even more $-65 \%$ in USA) have acquired wealth by starting business. Schumpeterian entrepreneurship is fundamentally related to innovation and an ambition to grow business, while small business activity is concerned with flexible employment forms. Therefore, according to authors these two are different concepts and shall be analysed separately.

Multiple studies have been conducted on decision making and small business owner behaviour. New typology of micro-firm owners-managers was suggested in a research exploring owner-manager views associated with growth and lifestyle issues (Jaouen \& Lasch, 2015). Differences in behaviour were associated with four profiles such as success, subsistence, hedonism and paternalism. Study finds out two types of owners who want to grow (associated with success and paternalism), and two types of owners who do not (subsistence, hedonism).

Owner-managers attitudes to the growth of their businesses were studied by Wahlgrén and Virtanen (2015), and their study revealed three types of growth motivators - economic, psychological and social, as well as impact of various stakeholders on owner's motivation.

Along with topicality of research, terminology has developed and broadened over time to indicate person responsible for a small enterprise. Jennings and Beaver (1995) indicated different names, such as: owner, manager, entrepreneur, as well as combination of names such as: entrepreneur-owner, entrepreneur-manager, owner-manager and entrepreneur-owner-manager for describing person responsible for small enterprise (Jennings \& Beaver, 1995). These terms demonstrate person's different attributes in the interest of the company.

The same authors formed a view on the management processes in as small firms. They suggested that management process in a small firm is unique and entirely different to management process in larger enterprises. It shall not be assumed that small firm management performs the same management process as performed in large companies by professional managers, only on a smaller scale.

An opinion exists among entrepreneurs that founder or owner have insufficient management capabilities compared to professional managers. Therefore, at certain point they shall be substituted by professional manager to avoid stagnation of company or decline of business performance. However, there are research data which do not support this opinion (Millers et al., 2016).

Willard et al. (1992) analysed 155 fast-growing high-tech companies in USA and did not find in overall, significant performance differences between founder-managed and professionally managed companies. According to this research, founder-managed enterprises were slightly smaller in size than professionally managed companies and were growing at a slightly lower rate. At the same time founder-managed enterprises demonstrated slightly higher rates of profitability, and these differences were not significant. 
Daily and Dalton study (1992) focused on role of the corporate chief executive officer (CEO) as a founder or as a business professional. They argued with researchers insisting on a transition from entrepreneurial management to professional management to sustain effective management operations and avoid disastrous results. Their research did not find significant differences between enterprises managed by founders and non-founder managers. Further they presented a different way to look at the role of CEOs in growing firms.

Gulbrandsen studied Norwegian private sector owner-managed joint-stock enterprises with more than 15 employees (Gulbrandsen, 1996). It was noticed that several differences between owner-management and professional chief executive exist. Owner-managers usually has a smaller degree of administrative specialization than an appointed CEO, however, decisions were no more centralized in owner-managed companies than in other enterprises. It was identified also that owner-managed companies use planning as a management tool to the same extent as other enterprises. In managing their enterprises, owner-managers seem to be influenced by concerns inherent in the ownership role as well as by institutional norms in the business community about how enterprises should be structured and governed. In overall, no significant performance differences were found between founder-managed companies and non-founder managed companies.

Impact of the transformational leadership, entrepreneurial competence and technical competence on firm performance via innovativeness in owner-managed SMEs was studied in Malaysia. Data gathered from 178 owner-managers of SMEs showed that there are significant relationships linking transformational leadership, entrepreneurial and technical competence with innovativeness, and linking innovativeness with firm performance (Ng \& Kee, 2018). According to this research, exception was the link between transformational leadership and process innovativeness.

Barth et al. (2005) analysed the relationship between family ownership and productivity, and they specially focused on the role of owner-management (Barth et al., 2005). Their research showed that family-owned firms demonstrated less productivity than non-family-owned firms. Differences in productivity researchers explained by different management regimes. If family-owned firms were managed by a person hired outside the owner family, they were equally productive as non-family-owned firms. When family-owned firm was managed by a person from the owner's own family, productivity was considerably lower.

A study of 1733 Chilean firms showed that firms under the influence of opportunity-oriented or family-oriented owner-managers may differ in their internal practices, purpose, strategies, and performance. One of findings from this research was that firms owner-managed by entrepreneurs who entered for a family-oriented reason finance their investment with firm resources, are less dependent on one customer and are willing to put forth less innovation effort than firms owner-managed by entrepreneurs who entered for an opportunity-oriented reason (Basco, 2019).

There are more studies to understand factors that influence SME performance and particularly, growth. According to small business performance research by Blackburn et al. (2013), size and age of enterprise dominated performance and were more important than strategies and owner's entrepreneurial characteristics Also, existence of the business plan in a company was noticed to have positive contribution to performance.

There are multiple factors that influence company performance, and owner-manager status or its role can be just few of them.

According to Donaldson, the contingency theory of organisations is major theoretical lens to view organisations, and some of more important contingency theories of organisation structure involve three contingencies of the environment, organisational size, and strategy (Donaldson, 1996). According to his conclusions, owner-managers' profile and their ownership portfolio was not as essential as awaited. Instead, business nature determines leadership pattern more than owner's personal qualities. His findings support further the contingency theory and defines that "recipe" for successful management is to regain fit.

Wang and Poutziouris also noted that there cannot be a single managerial style defined or a management structure that will work as a solution for organisational challenges (Wang \& Poutziouris, 2010). Therefore, leaders should understand the business contexts comprehensively to lead firms towards success and work out a "fit" on this basis matching strategy to organisational intrinsic and extrinsic nature.

Relationship between CEO's age and firm's performance in owner-managed private firms in three Western European countries was examined in research conducted by Belenzon et al. (2019). They found that as a CEO ages, the firm experiences lower investment, lower sales growth, and lower profitability, but also higher probability of survival, suggesting a trade-off between the managerial approaches of younger and older CEOs.

Several author pay specific attention to succession planning in family business (Gilding et al., 2015), owner managed firms (Stavrou, 2003) and in company transition to next generations (Marshall et al., 2006). These authors indicated on motives for succession planning and problems in planning and execution of succession and transition, which has ultimately negative effect on business.

European Commission introduced classification of the Small and Medium sized enterprises based on number of employees and two financial indicators - turnover and balance sheet. This classification does not reflect the differences between the different types of owners and how they manage their business.

Literature review shows that authors use many different terms and different ways for describing small and medium sized enterprises, their owners and approaches to way they manage and develop their business and enterprises. Terms are often overlapping, and no ready classification of business owners was identified so far. 
Previous studies mostly refer to owner-manager of the enterprise as an individual, who has own personal traits, styles and preferences. However, the previous research has limitations in representing all variety of owners-managers, which is determined by their different ownership status and managerial authorities in company.

One way to help researchers and educators understand the diversity of SME owners-managers is to group similar types of owners-managers and then develop profiles of these groups. This can be achieved by depicting the characteristics of each group using descriptions of the set of owners-managers, i.e. the owner-manager typology. Typology is a way of describing groups of respondents displaying different clusters of behaviours, attitudes or views of the world.

A typology generally consists of a set of descriptive names or "types", attached to thumbnail sketches of typical behaviour and/or attitudes for each group. Typologies or classifications use similarities of form and function to impose order on a variety of objects. Basically, they are intellectual constructs in which objects with similar relevant attributes are grouped together to meet the purposes of the classifier.

\section{Methodology}

Research started with a systematic rapid literature review using an overview method to understand previous studies on the management of SMEs and owner-managed companies, types and diversity of SME owners and managers.

Data for research were collected through 52 semi-structured interviews with SME owner-managers. Entrepreneurs and owners of businesses with at least 10 employees were selected for interviews. This allowed to focus on management specifics in small and medium sized enterprises and to avoid sole entrepreneurships or micro-enterprises. Entrepreneurs interviewed represented mainly businesses operating in Latvia, as well as few other European countries. Businesses represented different industries and different company age. The number of interviews was sufficient to reveal different types of owners-managers and different ways in which companies are managed. Interviews were conducted in period from 2016 till 2020.

Semi-structured interviews were aimed to understand role of owner-manager in company, his or her historical relationship to their business, and how company is managed. Interviews included questions such as:

- Was current owner-manager founder of particular company, or have entered company at later stage?

- Has owner-manager other co-founders, co-owners or other stakeholders?

- How independent is owner-manager in his/her decision making on business issues?

- How involved or how distant is owner-manager in daily management of his/her company?

- Is this person owner of single business or several business entities?

- What is the main purpose for the owner to have and manage this business?

Interviews usually lasted from 10 to 60 minutes and exposed circumstances and specifics how owners-managers manage their companies and make decisions on company and business development.

The owner-manager types were defined as a combination of several attributes. With the help of these attributes, the similarities and differences between the owners were adequately grasped. And finally, the constructed groups and types were described with the help of these properties. The main research approaches are deduction, induction and abduction. As result a preliminary typology of the SME's owners-managers was developed. Finally, descriptions for the constructed groups and types were created with the help of these properties.

Key findings and research results were discussed and approbated in two focus group discussions. Both focus groups were organised using the single focus group format with one moderator and group consisting of 9 university representatives, business consultants and entrepreneurs. Each tentatively proposed owner-manager type was discussed in focus group to confirm presence of such owners-managers in the SME segment, validate and modify proposed type names and descriptions.

\section{Results}

Literature review brought up a broad variety of terminology with a similar meaning in area of owner-managed SMEs. The "owner-manager" is just one term describing a person running own business. Other terms, such as "Founder managed company" or "Owner managed company" also carry meaning of person's role in a company and way of running business. Also, the "Family run business" presents such meaning. Term "Family business" at the same time is used to describe one of enterprise types. However, literature mostly refers to owner-manager of the enterprise as a sole and individual person. There are three defined forms of business - sole entrepreneurship, partnership and corporation. However, there was no formal typology of owners-managers found, which would provide holistic view and display differences in a proper way.

Interviews with entrepreneurs and owners-managers of small-medium sized companies identified range of specific circumstances on SME ownership and way how these companies are managed, and some of them were not identified during previous literature review:

- There are enterprises with single owner and with several owners (co-owners);

- Current owner of the enterprise can be founder of enterprise and can become owner in a later phase; 
- Owner-manager can be deeply involved in enterprise daily management and can be distant;

- Becoming company ownership and manager can be person's free choice, and can be result of external event or inevitable circumstances;

- Owner-manager can be independent and can be dependant from other stakeholders (co-founders, investors, family members);

- Owner-manager can manage single enterprise or several related or unrelated business entities;

- Business can be constructed as a single enterprise or as a combination of several legal entities with various legal forms and management structures.

Types of SME owners-managers defined as result of literature review and interviews are represented in Table 1.

As a result of several iterations, current version of typology consists of 10 types of SME owners-managers. Each type represented in Table 1 has own identification letter (from A to J), title name and brief description.

There is a distinction observed between founder of company and its owner. In case of sole entrepreneurship founder and owner usually is the same person. Also, in most of cases of micro-business, the founder is also an owner. In case of the SMEs, single founder-managed is one of types of SME owners-managers defined during this research (Type A in the Table 1).

It also shall be noted that SMEs often can have more than one founder or owner, and one of them is formally or officially declared as a manager (Type B in Table 1). To public both or all owners of such enterprise can state themselves as owners, but their decision-making and independence can be limited by written or informally defined process of communication with other business partners.

In case of SME there are occasions that founder can exit company by selling his or her shares fully or partially to another investor, manager or next owner. There can be several reasons for founder to exit his own company. One of reasons can be initial strategic decision to set up and develop company to certain stage and then sell it. Alternatively, such decision can be driven by other internal or external factors - financial problems, competition as well as lack of managerial skill or limited abilities of founder. There are situations when founder of company has attracted other co-owner with specific purpose or competence. It can be skilled manager/CEO motivated by defined shareholding in company (Type $\mathrm{C}$ in Table 1).

Table 1. Ten types of owners-managers of the SMEs (source: created by authors)

\begin{tabular}{|c|c|c|}
\hline & $\begin{array}{l}\text { Type of the SME } \\
\text { Owner-manager }\end{array}$ & Description of relevant situations in enterprise \\
\hline A & $\begin{array}{l}\text { Single } \\
\text { founder-manager }\end{array}$ & $\begin{array}{l}\text { Company is permanently managed by its original founder. Company can be new, growing or can } \\
\text { be mature, experienced. There also can be occasion when owner-founder returns to company } \\
\text { management after failed experience with hiring professional manager. }\end{array}$ \\
\hline $\mathrm{B}$ & Co-founder-manager & $\begin{array}{l}\text { Company established by two or more co-founders, with one of them acting as manager or the CEO. } \\
\text { Other founders can have supervisory role in Board or can hold other job position in company. }\end{array}$ \\
\hline $\mathrm{C}$ & Manager co-owner & $\begin{array}{l}\text { Company is managed by professional CEO who owns minority of shares of company as part of } \\
\text { motivational programme or special agreement. Other owners can hold supervisory or controlling } \\
\text { role in Board or can hold professional job position. }\end{array}$ \\
\hline $\mathrm{D}$ & Investor-1 & $\begin{array}{l}\text { Company is managed by person who became an owner as result of management buyout, financial } \\
\text { or strategic investment. Investor's long-term or short-term intentions can have been declared openly } \\
\text { or kept hidden. }\end{array}$ \\
\hline $\mathrm{E}$ & $\begin{array}{l}\text { Business "cluster" } \\
\text { owner }\end{array}$ & $\begin{array}{l}\text { There is a group of smaller enterprises or organisations working closely in related business, } \\
\text { established or owned by one person. Companies in group can have also other co-owners or } \\
\text { partners. Enterprises in group can have various legal statuses (commercial, non-profit, fund). }\end{array}$ \\
\hline $\mathrm{F}$ & $\begin{array}{l}\text { Multi-business } \\
\text { owner }\end{array}$ & $\begin{array}{l}\text { There are several companies owned and managed by the same person which all operate in diverse } \\
\text { or unrelated businesses (such as production and leisure, or other). Usually, management effort in } \\
\text { these companies also is part-time or unequal. }\end{array}$ \\
\hline $\mathrm{G}$ & $\begin{array}{l}\text { Family business } \\
\text { manager }\end{array}$ & $\begin{array}{l}\text { Enterprise which belongs formally or "as a fact" to one family, have several family members } \\
\text { employed in various management and professional positions, formally and informally. }\end{array}$ \\
\hline $\mathrm{H}$ & $\begin{array}{l}\text { "Had-to-become" } \\
\text { owner-manager }\end{array}$ & $\begin{array}{l}\text { Enterprise has obtained new owner-manager due to some inevitable event (such as sickness or } \\
\text { death of previous owner, partner's divorce or another crisis) or other irresistible event (such as } \\
\text { partner's gift). New owner-manager usually is a family member or close relative. }\end{array}$ \\
\hline I & Owner-supervisor & $\begin{array}{l}\text { Owner of the SME have recruited and nominated acting Director (or CEO) with certain delegated } \\
\text { authorities who is in charge for daily management of the enterprise. Owner holds formal or } \\
\text { informal Supervisory role over his/her enterprise. }\end{array}$ \\
\hline $\mathrm{J}$ & Cast-away-owner & $\begin{array}{l}\text { Original owner has left company alone on its way due to personal problems (sickness, addiction, } \\
\text { personal tragedy, stress, etc.). Company is managed by some formal or informal leader-manager in } \\
\text { a "survival mode" and with formal or informal authority. }\end{array}$ \\
\hline
\end{tabular}


Company can also be taken over and managed further by strategic or financial investor (Type D in Table 1). Such manager usually has clear goal, which can be declared openly or kept confidential to employees. Both Type C (Manager-co-owner) and Type D management (Investor-manager) can be observed as result of companies' acquisitions or mergers.

There are many variations how ownership and influence is split between partners who are co-owners. Frequently shares and power are split un-equally, allowing one person to have key role in decision making. However, there are also cases where co-owner is other legal entity such as investment fund or strategic partner with its own management and control routines. It can lead to situation when holding majority of shares does not give equal decision-making power and independence.

Process of setting up new business has become easier over last years. Also, specific support programmes have become available for newly established companies or companies operating in specific field, specified territories or under special legal frameworks. It becomes widespread that one business owner holds more than one company or have spilt operations and risks among several legal entities. These legal entities can operate in a coordinated manner as a "cluster" (Type E in Table 1).

One owner can also own and manage several totally independent or differentiated by their nature business (Type $\mathrm{F}$ in Table 1). When business is operated as group of several legal entities, it is possible that some of companies in this "cluster" according to number of employees can be defined as "micro-enterprises", however total size of group corresponds to criteria of SME.

It was noticed that in some occasions "clusters" or similar company groups are established not by one person but in cooperation with friends, business partners or relatives. Therefore, such form of business cannot be identified through searching information in legal registers. Some family businesses are organised in a similar way.

Family-based business can have different forms, and this is not always reflected in formal company ownership structure or management structure. Family business manager is identified as a separate type (Type G in Table 1). Companies which formally belongs to one person and engage family members as employees or operates on family property (land, building, premises) from the outside may resemble an ordinary Limited Liability Company (Ltd.), however organisation's behaviour resembles more family business than commercial company.

Literature review indicated several aspects related to succession planning in owner-managed SMEs and transition to next generations in family business. Interviews also pointed out that some of business owners-managers have become such as result of some tragic event (death of family member, or divorce) or act of generosity by parents, spouse or supportive business angel. This type of owner-manager is identified as a separate type (Type $\mathrm{H}$ in Table 1). In such cases owner-manager role often requires from person much higher effort that as planned step in own business and career development. Interviews pointed out several steps out of this situation. There were occasions when new becoming owner held management role temporarily, until professional manager was hired, or business was sold. Also, cases were present when new owner successfully acquired the new role and continued to act successfully as manager.

Type I in this typology is reserved for those cases when owner of the enterprise has recruited professional manager, managing director or CEO for daily management of the enterprise. In this case the owner formally is not acting as manager of enterprise, however it holds certain control and supervisory role, which is defined by formal or informal delegation of authorities to the acting manager or CEO.

There are also a few seldom cases when owner of the enterprise has lost interest or ability to manage company, and some of employees for themselves takes over care for all business and processes. Such type of owner-manager in provided typology is named as Cast-away-owner (Type J in Table 1). Such owner's inability to manage enterprise can be caused by long-lasting disease, sudden accident, progression of unhealthy habits or addictions, psychical disorders resulting from personal drama, commercial failures or high risks taken.

All of these ten types of SME owners-managers defined and described in this research are present in current business environment. All owners-managers interviewed can be associated with certain type from provided typology. Developed typology and relevance of 10 types was confirmed also in two focus groups.

It was noticed during interviews that owners-managers of SMEs choose to use different terminology for describing their own role in company. While one is emphasising his/her role as founder or co-founder, other prefer to be named as partner or CEO. Each respondent has own motives and different intents that drives their choice and behaviour.

Interviews and focus group discussions confirmed that there is a need for such typology and type definitions to have a better understanding on owner-managed companies, especially SMEs.

In was pointed out in several interviews, as well as in focus group discussions, that ownership structure, managerial role and style can change over time and at the different stages of business development. Consequently, also the owner-manager type is not static for particular person and it can change over time and at different stages of business development. This should be taken into account in the further development of management research, entrepreneurship training and management development activities. 


\section{Discussion}

Systematic literature review shows that researchers use different terminology and different ways for describing small and medium sized enterprises, their owners and ways they manage and develop their business. Owner-manager of enterprise often is described as an individual. However, the previous research has limitations in representing all variety of owners-managers, which is determined by their different ownership status and managerial authorities in company.

It also shall be noted that European Commission recommendations on SME classification by number of employees entered into force on 1 January 2005. This classification suggested category named "Microenterprise" - enterprise with less than 10 employees. Therefore, conclusion and recommendations from earlier publications which refers to "Small business" shall not be automatically applied to all the SME segment as it is defined nowadays.

10 types of the owners-managers from typology provided in this article reflect diversity of the SME owners-managers well enough. Each type is associated with particular enterprise conditions or ownership circumstances creating certain situations. Provided typology attempts to cover whole SME segment and to include all possible types and variations of SMEs owners-managers.

SME owner-manager types defined in this research can be identified mostly through owner-manager self-assessment or guided interview. Owner-manager type cannot be identified using enterprise register data or other formal databases. State registers handle every legal entity initially as separate business. However, this research pointed out situations when business consists of several inter-related or independent legal entities. It can be expected that variety of forms of organising business will increase in the future in order to manage increasing complexity in business environment, to mitigate possible business risks and explore more opportunities provided by legislative, financial and social incentive mechanisms. It can be assumed also that new ways of ownership and management of small and medium-size enterprises can arise in future along with traditional role of company owner and manager.

Understanding of owner-manager type can lead to better understanding of his/her behaviour model, formal or informal decision-making process and can ultimately lead to better decision-making on business and personal development issues.

Recent events and market trends, such as pandemic, technological developments, new business models, open up also new opportunities for building businesses, organizing management processes, ownership structure, financing and management. The understanding of how business owners run and manage their businesses also needs to progress accordingly.

Owner-manager typology derived in this research and its interpretation can be elaborated further to improve understanding on way how owners-managers plan, control and manage their business, what are drivers or limitations on their decisions, and what competences are needed to be developed.

\section{Limitations}

Conclusions from this research are relevant to those SMEs analysed in this particular research and shall not be generalized without additional research and validation.

\section{Conclusions}

Ten types of owners-managers of the small and medium sized enterprises are defined and described in this research. In current version they are named as following: (A) Single founder-manager; (B) Co-founder - manager; (C) Manager co-owner; (D) Investor-manager; (E) Business "cluster" owner; (F) Multi-business owner; (G) Family business manager, (I) "Had-to-become" owner-manager; (I) Owner-supervisor, and (J) Cast-away-owner.

For each type there is a relevant example of enterprise situation or owner's personal circumstanced described as these factors impact behaviour of owner-manager.

It was confirmed during interviews and in focus groups, that all ten types of SME owners-managers defined and described in this research are present in current business environment. Ownership structure, managerial role and style can change over time, consequently, also the type of owner-manager is not fixed with particular person and can change over time and at different stages of business development. This is important to be noticed in management research, entrepreneurship training and management development.

This research is an attempt to cover whole Small and Medium sized enterprise segment (companies with 10 to 249 employees) and create typology that includes all possible types of SMEs owners-managers.

It was noticed that Europe started to use new classification of SME size and three categories in 2005. It shall be noted that literature and data on Small business before this period and after may correspond to enterprises nowadays defined as "microenterprise" rather than "small business". Conclusions from such literature and research shall not be automatically applied to all the SME segment as it is defined nowadays. 
This research raises understanding of diversity of owners-managers of the SMEs and suggest new typology. The proposed typology is a step towards filling the knowledge gap caused by the lack of a holistic and systematic approach in addressing the diversity of the SME owners-managers. Research shall be continued with more in-depth analysis of literature and research of the SME management practices also beyond Latvia and Baltics region.

\section{Disclosure statement}

Authors declare that they do not have any competing financial, professional, or personal interests from other parties.

\section{References}

Barth, E., Gulbrandsen, T., \& Schoø, P. (2005). Family ownership and productivity: The role of owner-management. Journal of Corporate Finance, 11(1-2), 107-127. https://doi.org/10.1016/j.jcorpfin.2004.02.001

Basco, R. (2019). What kind of firm do you owner-manage? An institutional logics perspective of individuals' reasons for becoming an entrepreneur. Journal of Family Business Management, 9(3). https://doi.org/10.1108/JFBM-09-2018-0032

Belenzon, S., Shamshur, A., \& Zarutskie, R. (2019). CEO's age and the performance of closely held firms. Strategic Management Journal, 40(6), 917-944. https://doi.org/10.1002/smj.3003

Birch, D. L. (2000). The job generation process. In D. J. Storey (Ed.), Small business: critical perspectives on business and management (pp. 431-454). Routledge. https://books.google.lv/books?hl=lv\&lr=\&id=2tx13ix6X84C\&oi=fnd\&pg=PA431\&ots=AjwIc1wNGh\&sig=Ef3LUEXI-lt8SRvYjkiRSj8z3Ts\&redir_esc=y\#v=onepage\&q\&f=false

Birley, S., Ng, D., \& Godfrey, A. (1999). The family and the business. Long Range Planning, 32(6), 598-608. https://doi.org/10.1016/S0024-6301(99)00076-X

Blackburn, R. A., Hart, M., \& Wainwright, T. (2013). Small business performance: business, strategy and owner-manager characteristics. Journal of Small Business and Enterprise Development, 20(1), 8-27. https://doi.org/10.1108/14626001311298394

Carland, J. W., Hoy, F., Boulton, W. R., \& Carland, J. A. (1984). Differentiating entrepreneurs from small business owners. The Academy of Management Review, 9(2), 354-359. https://doi.org/10.2307/258448

Coetzer, A., Wallo, A., \& Kock, H. (2019). The owner-manager's role as a facilitator of informal learning in small businesses. Human Resource Development International, 22(5). https://doi.org/10.1080/13678868.2019.1585695

Daily, C. M., \& Dalton, D. R. (1992). Financial performance of founder-managed versus professionally managed small corporations. Journal of Small Business Management, 30, 25-34.

Deeks, J. S. (1970). The owner manager. Industrial \& Commercial Training, 2(7), 326. https://doi.org/10.1108/eb003069

Dhaliwal, D. S., Salamon, G. L., \& Dan Smith, E. (1982). The effect of owner versus management control on the choice of accounting methods. Journal of Accounting and Economics, 4(1), 41-53. https://doi.org/10.1016/0165-4101(82)90005-2

Donaldson, L. (1999). The normal science of structural contingency theory. In S. R. Clegg \& C. Hardy (Eds.), Studying organization: Theory \& method (pp. 51-70). SAGE Publications Ltd. https://www.doi.org/10.4135/9781446218556.n2

European Commission. (2005). The New SME definition. Official Journal of the European Union, C(October), 1-52. https://doi.org/EN NB60-04-773-ENC-C 92-894-7909-4

European Commission. (2017). Annual Report on European SMEs 2016/2017: Focus on self-employment. In SME Performance Review. https://doi.org/10.2873/742338

European Commission. (2019). Annual Report on European SMEs 2018 / 2019 (Annual Report). https://op.europa.eu/en/publication-detail/-/publication/cadb8188-35b4-11ea-ba6e-01aa75ed71a1/language-en

Gilding, M., Gregory, S., \& Cosson, B. (2015). Motives and outcomes in family business succession planning. Entrepreneurship: Theory and Practice. https://doi.org/10.1111/etap.12040

Goffee, R., \& Scase, R. (1985). Proprietorial control in family firms: some functions of 'quasi-organic' management systems. Journal of Management Studies, 22(1), 53-68. https://doi.org/10.1111/j.1467-6486.1985.tb00242.x

Gulbrandsen, T. (1996). All power in one pair of hands? Governance of owner-managed business enterprises. Tidsskrift for Samfunnsforskning, 37(3), 363-391.

Henrekson, M., \& Sanandaji, T. (2014). Small business activity does not measure entrepreneurship. In Proceedings of the National 111(5), 1760-1765. https://doi.org/10.1073/pnas.1307204111

Ikuta, R. (2000). Small business problems and policy in the United States during the 1930s. Keiei Shigaku (Japan Business History Review), 35, 1-27. https://doi.org/10.5029/bhsj.35.4_1

James, H. S. (Jr). (1999). Owner as manager: extended horizons and the family firm. International Journal of the Economics of Business, 6(1), 41-55. https://doi.org/10.1080/13571519984304

Jaouen, A., \& Lasch, F. (2015). A new typology of micro-firm owner-managers. International Small Business Journal, 33(4), 397-421. https://doi.org/10.1177/0266242613498789

Jennings, P. L., \& Beaver, G. (1995). The managerial dimension of small business failure. Strategic Change, 4(4), $185-200$. https://doi.org/10.1002/jsc.4240040402

Marshall, J. P., Sorenson, R., Brigham, K., Wieling, E., Reifman, A., \& Wampler, R. S. (2006). The paradox for the family firm CEO: Owner age relationship to succession-related processes and plans. Journal of Business Venturing, 21(3), 348-368. https://doi.org/10.1016/j.jbusvent.2005.06.004

Millers, M. (2017). Diversity of owner managed Small and Medium Enterprises. In Contemporary Challenges in Management and Economics Special Section for Doctoral Students. Within Icem-2017. 
Millers, M., Gaile-Sarkane, E., \& Sceulovs, D. (2016). Owner-managed company: an advantage or a challenge? In Smart and efficient economy: preparation for the future innovative economy (pp. 579-585). ICEM. http://www.icem.lt/public/icem/ ICEM 2016 selected papers.pdf

Ng, H. S., \& Kee, D. M. H. (2018). The core competence of successful owner-managed SMEs. Management Decision, 56(1). https://doi.org/10.1108/MD-12-2016-0877

Organisation for Economic Co-operation and Development. (2020). Covid-19: SME Policy Responses. https://www.oecd.org/ coronavirus/policy-responses/coronavirus-covid-19-sme-policy-responses-04440101/

Schein, E. H. (1995). The role of the founder in creating organizational culture. Family Business Review, 8(3), 221-238. https://doi.org/10.1111/j.1741-6248.1995.00221.x

Schumpeter, J. A. (1934). The theory of economic development. Harvard University Press.

Stavrou, E. T. (2003). Leadership succession in owner-managed firms through the lens of extraversion. International Small Business Journal, 21, 331-347. https://doi.org/10.1177/02662426030213005

Ščeulovs, D., \& Gaile-Sarkane, E. (2012, 10-11 May). Classification of micro and small enterprises. In 7th International Scientific Conference "Business and Management 2012" (pp. 1231-1238). Vilnius, Lithuania. https://doi.org/10.3846/bm.2012.158

Wahlgrén, A., \& Virtanen, A. (2015). Owner-managers' motivation and the growth of family-owned small and medium-sized enterprises. International Journal of Entrepreneurship and Small Business, 26(3), 293-311. https://doi.org/10.1504/IJESB.2015.072393

Wang, C., Walker, E., \& Redmond, J. (2007). Explaining the lack of strategic planning in SMEs: the importance of owner motivation. International Journal of Organizational Behaviour, 12(121), 1-16.

Wang, Y., \& Poutziouris, P. (2010). Leadership styles, management systems and growth: empirical evidence from UK owner-managed SMEs. Journal of Enterprising Culture, 18(3), 331-354. https://doi.org/10.1142/S0218495810000604

Willard, G. E., Krueger, D. A., \& Feeser, H. R. (1992). In order to grow, must the founder go: A comparison of performance between founder and non-founder managed high-growth manufacturing firms. Journal of Business Venturing, 7(3), $181-194$. https://doi.org/10.1016/0883-9026(92)90025-M 